\title{
Material Tester Using Pendulum
}

\author{
Hitomi ItoＮon-member (Gunma University, m06e607@gs.eng.gunma-u.ac.jp ) \\ Yusaku Fujii Member (Gunma University, fujii@el.gunma-u.ac.jp ) \\ Takao YamaguchiＮon-member（Gunma University, yamagme4@me.gunma-u.ac.jp ) \\ Yoichi Sugita Non-member (Gunma University, m07e627@gs.eng.gunma-u.ac.jp ) \\ Masayuki Yokota Non-member (Gunma University, yokota@el.gunma-u.ac.jp )
}

Keywords : levitation mass method, optical interferometer, mechanical characteristics, pendulum

A practical and low cost instrument for accurately measuring small impact force is proposed. In the various industrial and research applications such as materials testing, the requirements for evaluating the mechanical characteristics of materials and structure have increased. The second author has proposed the levitation mass method (LMM) that can generate and measure a varying force. In the past, the material tests have conducted by means of the LMM. In this method, a mass is levitated using a pneumatic linear bearing. However, the pneumatic linear bearing needs an expensive air compressor and mechanism is exact and complicated. In addition, the pneumatic linear bearing can not be applied in an extrenaly high or low temperature, or vacuum environments. In this paper, the mechanical characteristics of material against small impact force are investigated by means of the newly developed pendulum mechanism. In this method, a pendulum mechanism with 6 wires is used to realize the static motion of mass which is the swing part of pendulum. Mass is suspended by 3 triangles formed using 6 wires. During the measurement, only the Doppler shift frequency of the laser light reflecting on the mass is highly accurately measured using an optical interferometer. The velocity, position, acceleration and inertial force of the mass are calculated from the measured time-varying Doppler frequency shift.

Figure 1 shows the schematic diagram of the experimental setup developed for measuring the mechanical characteristics of material against small impact forces.

In the experiment, free-swing measurement and collision measurement are conducted. To evaluate the restoring force of pendulum, the free-swing measurement is conducted. In the

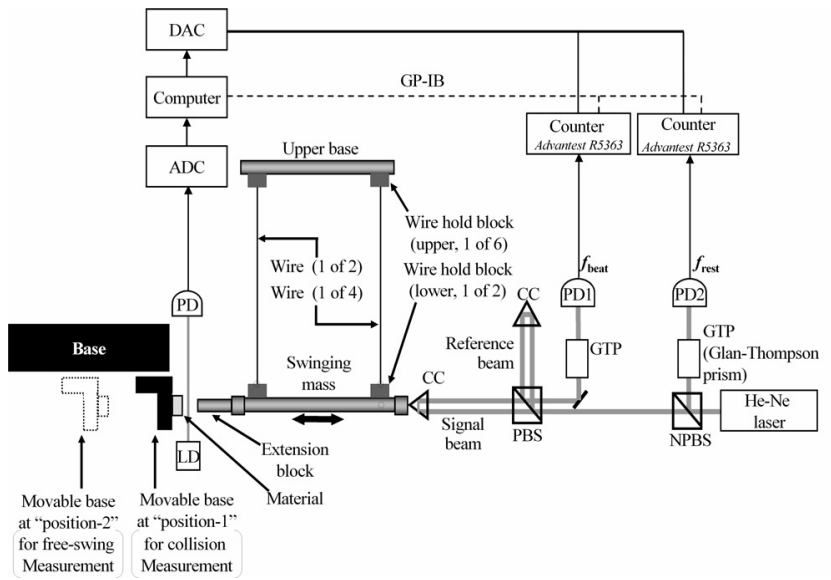

Fig. 1. Experiment setup collision measurement, the total force acting on the mass is measured.

Figure 2 shows the change in the restoring force, Frestoring, against position. The linear regression equation is $\boldsymbol{F}_{\text {regression }}=$ $-33.456 x$. The coefficient of determination $\left(\mathrm{R}^{2}\right)$ is approximately 0.9991 .

Figure 3 shows the change in the corrected force, $\boldsymbol{F}_{\text {corrected }}=$ $\boldsymbol{F}_{\text {mass }}-\boldsymbol{F}_{\text {regression }}$, against position. To obtain the corrected force,

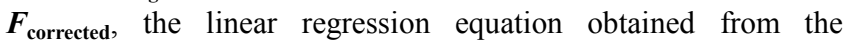
free-swing measurement, $\boldsymbol{F}_{\text {regression }}=-33.456 \boldsymbol{x}$, is used. Elastic hysteresis, which is caused by the viscosity of material, is clearly observed.

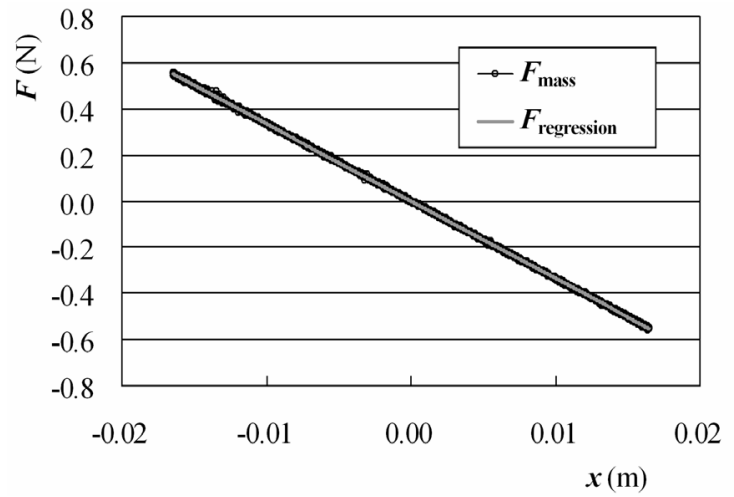

Fig. 2. Change in the restoring force, $\boldsymbol{F}_{\text {restoring, against }}$ position

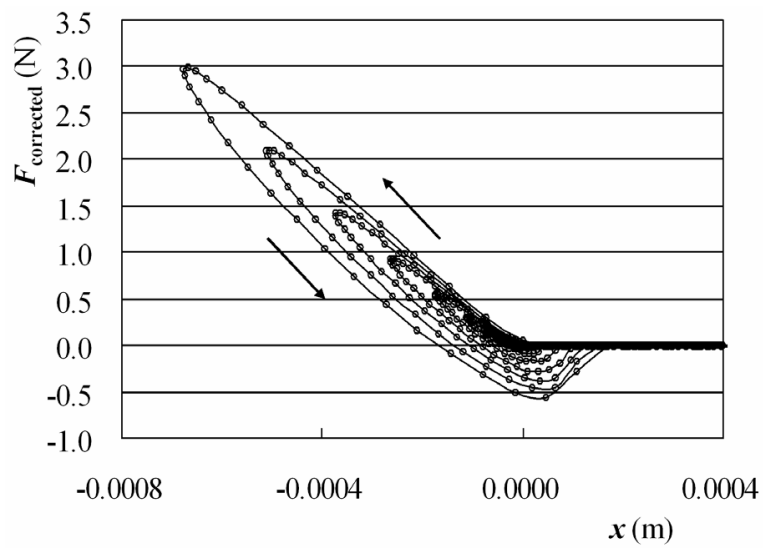

Fig. 3. Change in the corrected force, $\boldsymbol{F}_{\text {corrected }}=\boldsymbol{F}_{\text {mass }}$ $-\boldsymbol{F}_{\text {regression }}$, against position 


\title{
振子機構を用いた材料試験
}

$\begin{array}{lrrrrr}\text { 非会員 } & \text { 伊藤 } & \text { 瞳* }^{*} & \text { 正 } \text { 員 } & \text { 藤井 } & \text { 雄作* } \\ \text { 非会員 } & \text { 山口 } & \text { 誉夫* } & \text { 非会員 } & \text { 杉田 } & \text { 陽市* } \\ \text { 非会員 } & \text { 横田 } & \text { 正幸* } & & & \end{array}$

\section{Material Tester Using Pendulum}

Hitomi Ito*, Non-member, Yusaku Fujii*, Member, Takao Yamaguchi*, Non-member, Yoichi Sugita*, Non-member, Masayuki Yokota*, Non-member

\begin{abstract}
A practical and low cost instrument for accurately measuring small impact force is proposed. In the various industrial and research applications such as materials testing, the requirements for evaluating the mechanical characteristics of materials and structure have increased. In this paper, the mechanical characteristics of material against small impact force are determined by means of the newly developed pendulum mechanism that based on the levitation mass method (LMM). In this method, a pendulum mechanism is used as a substitute for expensive pneumatic linear bearing. A mass that is suspended using a newly developed pendulum mechanism with negligible friction and a stable restoring force, is made to collide with the object under test. A pendulum mechanism with 6 wires is used to realize the static motion of mass that is the swing part of pendulum. Mass is suspended by 3 triangles formed using 6 wires. The Doppler frequency shift of a laser beam reflecting on the mass is highly accurately measured using an optical interferometer. The velocity, position, acceleration and inertial force of the mass are calculated from the measured time-varying Doppler frequency shift. The performance of the proposed method is demonstrated by evaluating the viscoelasticity (i.e. hysteresis curve between force and displacement, curve between force and velocity) of a small silicon-gel block under an impact load.
\end{abstract}

キーワード : 浮上質量法, 光波干涉計, 力学特性, 振子

Keywords : levitation mass method, optical interferometer, mechanical characteristics, pendulum

\section{1. 背 景}

近年，材料試験，金属工業，運動制御など様々な工業や 応用研究の分野において, 材料や構造体の機械特性評価の 必要性が高まっている。評価方法として，材料に作用する 力はカセンサを用いて測定され，材料の位置は変位センサ によって測定される。しかしながら，力センサは一般的に 静的環境下において分銅を使った方法で校正される。現在， カセンサの動的特性を評価するための基準方法はない。力 センサの動的校正方法は未だ確立されていないが，力セン サに対する動的校正法としていくつかの試みがある。その 一つは, ドイツの国立標準研究所である物理工学研究所 (PTB) において,「連続振動力に対する動的校正法」に関す る研究開発が進められている(1) (3)。

\footnotetext{
* 群馬大学工学部電気電子工学科

干376-8515 群馬県桐生市天神町 1-5-1

Department of Electronic Engineering., Faculty of Engineering., Gunma University.

1-5-1 Tenjinchou, Kiryuusi, Gunma 376-8515
}

一方, 著者らは既存のカセンサを用いない浮上質量法(4) (13) を提案している。浮上質量法では, 空気圧で浮上支持した 質量の慣性力は, 質量と加速度の積として求められ, 質量 の加速度は光波干渉計を用いて高精度に測定される。著者 らはこれまで, 浮上質量法に基づいた, 衝撃応答(4), ステッ プ応答 ${ }^{(5)}$, 振動応答 ${ }^{(6)}$ に対する力センサの動的校正法を提 案・開発している(4) (6)。

また, 浮上質量法を応用して材料試験 ${ }^{(7)}$ (10)を行ってき た。さらには, 空気軸受内部に働く摩擦力評価法 ${ }^{(1)}$, マイ クロニュートンレベルの力の発生・計測法 ${ }^{(12)}$ も開発してい る。

浮上質量法を用いた測定において，空気軸受は十分に小 さな動摩擦力での直線運動を実現するために用いられる。 しかしながら, 空気軸受は高価な空気圧縮機を必要とし, 機構が精密で複雑である。また非常に高温・低温な環境, 真空環境では使用が困難である。そこで, 空気軸受の代わ りとして, 実用的で安価, かつ小型の装置開発が必要であ る。 
本論文では，微小な衝撃力を正確に測定するための実用 的で低コストな装置を提案する。著者らは以前に 4 本ワイ ヤー支持の振子機構を開発している(13)。しかしながら，以 前に提案した振子は，4本のワイヤーで形成される 2 つ台 形によって吊るされており，スイング部の動きを一方向に 制御できず，スイング部の動きが安定していなかった。そ こで，振子のスイング部の安定した動きを実現するため，6 本ワイヤー支持の振子機構を開発した。スイング部は，6本 のワイヤーで形成される 3 つの三角形によって吊るされて いる。

また，この振子機構は，慣性質量の支持機構として空気 軸受を用いた場合と同程度の精度である不確かさ $0.2 \%$ から $0.3 \%$ 程度 ${ }^{(8) \sim(10)}$ を目標とする。

本論文では，6本ワイヤー支持の振子機構を用い，シリコ ンゲルを試料として，粘弾性材料の材料試験を行った。粘 弾性材料の力学モデルには, 多くのモデルが提案されてお り,さらに現在も研究が続けられている。しかし，いずれ のモデルも基本的には力一変位間の履歴曲線, 力一速度間 の履歴曲線などを関数近似することでパラメータを得る。 したがって関数近似によって誤差が導入される可能性があ る。本論文では, そのような関数近似の誤差を出来る限り 含まれない条件, 寸なわち力一変位間の履歴曲線, 力一速 度間の履歴曲線の原波形で, 提案計測法の精度を議論して いく。

\section{2. 実験装置}

Fig. 1 には，実験装置の概略図を示す。実験装置は主に振 子とマイケルソン型ヘテロダイン干涉計で構成されてい る。干渉計の光源から射出された二つの直交偏光を持つレ ーザ光はまず, 無偏光ビームスプリッタ (NPBS) により二 分される。二分されたレーザ光の一方は, そのまま偏光板 (GTP) を通しフォトダイオード (PD2) により電気信号と して取り出される。また, NPBSにより二分されたもう一方 のレーザ光は, 再び偏光ビームスプリッタ (PBS) により信 号光と参照光に分離される。参照光は固定されたコーナー キューブプリズム (CC) により反射され, 信号光は振子に

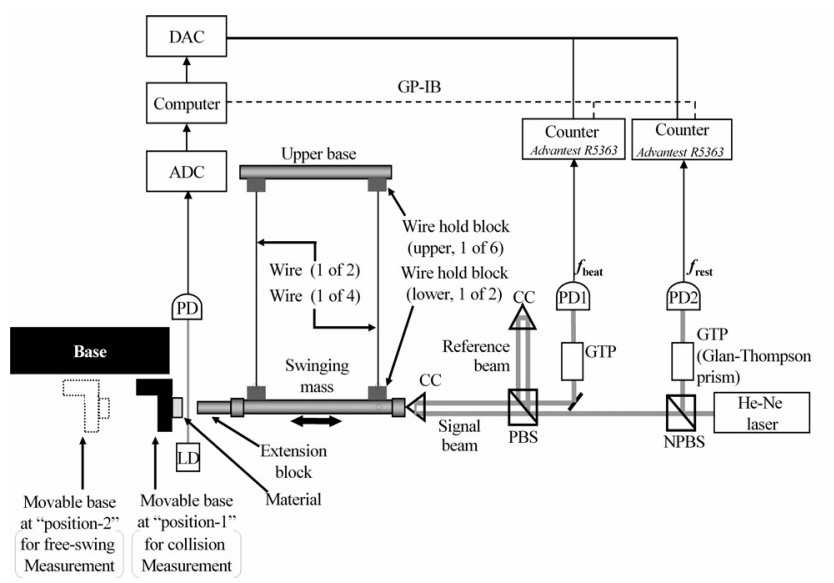

Fig. 1. Experiment setup.
取り付けられた CCにより反射される。CCにより反射され た信号光と参照光は GTP を通して干渉し, PD1 により取り 出される。本実験では, 質量の慣性力は試料に作用する参 照力として使用される。衝撃力は, 質量と試料の間で衝突 を引き起こすことによって発生させる。

Fig. 2 には, 実験装置の写真を示す。(a)には, 今回実験に 使用した 6 本ワイヤー支持の振子機構, (b)には, ワイヤー の長さ調節用巻き機構の拡大写真を示す。実験に用いた振 子の可動部は, 試料に衝突する金属ブロック, 干渉計のた めのコーナーキューブプリズム (CC), ワイヤー保持ブロッ クで構成されている。金属ブロックの先端は平らな形状で ある。振子の可動部の総質量は約 $0.78222 \mathrm{~kg}$ である。振子 は，定盤に固定されたアッパーベースから 6 本のワイヤー により形成される 3 つの三角形によって吊るされている。2 本のワイヤーとアッパーベースでそれぞれ三角形を形成し ている。ワイヤーは, ワイヤー保持ブロックで振子本体と アッパーベースにそれぞれ固定される。各ワイヤーは直径 約 $0.1 \mathrm{~mm}$, 長さ約 $235 \mathrm{~mm}$ である。各ワイヤーの長さ調節 機構として，ギターに用いられるペグを使用した。

Fig. 3 には振子の模式図を示寸。以前は(a)に示す 4 本ワイ ヤーの振子を用いていたが，スイング部の動きを一方向に 安定させることが出来なかった。今回用いた(b)に示す 6 本 ワイヤーの振子では, ペアのワイヤー3 組で三角形を形成寸 ることで，安定した一方向運動を実現した。

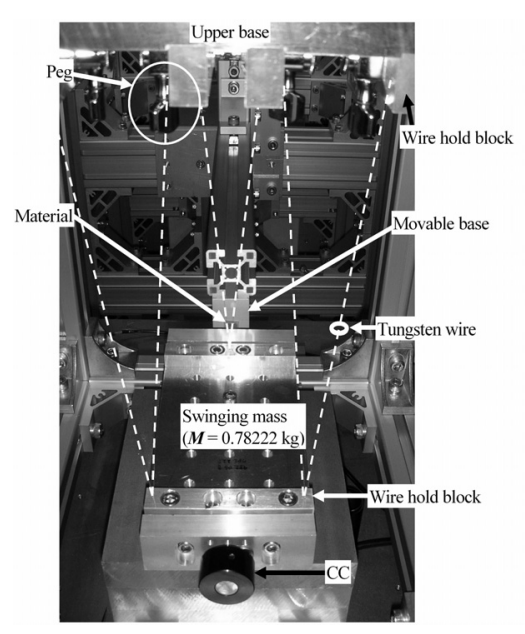

(a) Pendulum mechanism

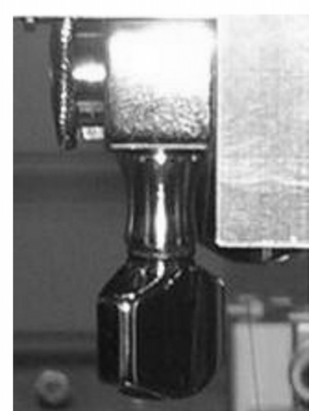

(b) Winding mechanism
Fig. 2. Photograph around test section.

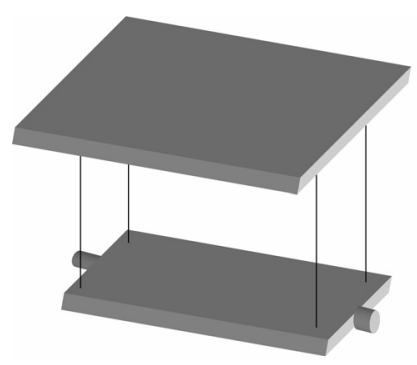

(a) 4 wires

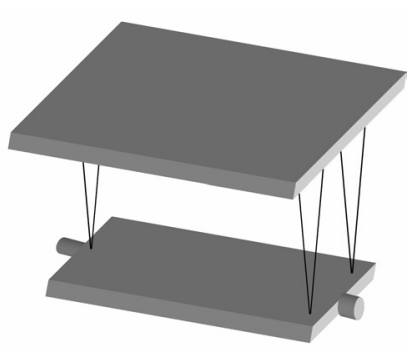

(b) 6 wires

Fig. 3. Schematic of the pendulum. 
実験は，次の手順で行う。まず，細い合成繊維を使い， スイング部を Fig. 1 での右方向に引っ張る。次に, 極力振動 を与えないようカッターを使い, 静かに糸を切断すること により，可動部はスイングし始める。質量に作用する慣性 力は, 質量の加速度から計算される。質量の加速度は光波 干渉計を使って高精度に測定される。

本実験では，試料としてシリコンゲル片を用いた。この シリコンゲル片は定盤に取り付けられたベースに固定され る。このベースは可動式で, 衝突実験とフリースイング実 験の 2 種類の実験に併用できる。Fig. 1 では, 可動ベースは 衝突実験用に“position-1”にセットされている。“position-2” での可動ベースを破線で示している。振子の復元力評価用 のフリースイング実験では，可動ベースを “position-2”に セットし，スイング部は復元力によって前後に動く。スイ ング部に作用する力 $\boldsymbol{F}_{\text {mass }}$ は質量 $\boldsymbol{M}$ と加速度 $\boldsymbol{a}$ の積として計 算される。スイング部に作用する力 $\boldsymbol{F}_{\text {mass }}$ は, 次式で表すよ うに, 試料から作用する力 $\boldsymbol{F}_{\text {material }}$ と振子の復元力 $\boldsymbol{F}_{\text {restoring }}$ に分けられる。

$$
\boldsymbol{F}_{\text {mass }}=\boldsymbol{F}_{\text {material }}+\boldsymbol{F}_{\text {restoring }}
$$

実験では, 力 $\boldsymbol{F}_{\text {mass }}$ は質量と加速度の積として求められる。 加速度は，スイング部の速度から計算される。速度 $v$ は, 測 定したドップラーシフト周波数 $\boldsymbol{f}_{\text {Doppler }}$ から，実験環境下に おける空気中でのレーザの波長 $\lambda_{\text {air }}$ を用いて, 次式のように 求められる。

$$
\begin{aligned}
& \boldsymbol{v}=\lambda_{\text {air }}\left(\boldsymbol{f}_{\text {Doppler }}\right) / 2 \ldots \ldots \ldots \ldots \\
& \boldsymbol{f}_{\text {Doppler }}=-\left(\boldsymbol{f}_{\text {beat }}-\boldsymbol{f}_{\text {rest }}\right)
\end{aligned}
$$

$\boldsymbol{f}_{\text {beat }}$ は信号光と参照光の差周波数, $\boldsymbol{f}_{\text {rest }}$ は, 可動部が静止し た状態での $f_{\text {beat }}$ の值である。速度，位置，加速度，力の座 標方向は, Fig. 1 の右側を正方向としている。

干渉計の光源には, ゼーマンタイプの 2 周波数 $\mathrm{He}-\mathrm{Ne} レ$ 一ザを使用する。本実験では，周波数 $\boldsymbol{f}_{\text {beat }}$ 及び $\boldsymbol{f}_{\text {rest }}$ のみを測 定する。信号光と参照光の差周波数 $\boldsymbol{f}_{\text {beat }}$ は, 光波干渉計の 出力に現れる干渉縞から測定され, 運動の速度に依存して, 参照光の周波数 $\boldsymbol{f}_{\text {rest }}, 2.75 \mathrm{MHz}$ を中心として変化する。周波 数カウンタ (model R5363, manufactured by Advantest Corp., Japan) は連続的に測定し, 休止時間なしに $\boldsymbol{T}=4000 / \boldsymbol{f}_{\text {beat }}$ の サンプリング間隔で 6000 個のビート周波数 $\boldsymbol{f}_{\text {beat }}$ を記録し, メモリに值を保存する。2.75 MHz で周波数カウンタのサン プリング間隔は約 $1.5 \mathrm{~ms}$ である。同様に， $\boldsymbol{f}_{\text {rest }}$ を同じモデル の別の周波数カウンタで測定する。

2 台の周波数カウンタを使った測定は, $\mathrm{AD}$ 変換機を使っ て発生させたトリガー信号によって開始される。

\section{3. 測 定}

実験では，衝突実験とフリースイング実験の 2 種類の実 験を行う。フリースイング実験は, 振子の復元力 $\boldsymbol{F}_{\text {restoring }}$ 評価するための実験である。

Fig. 4 には，フリースイング実験の結果の一部を示してい る。(3)式により計算される周波数 $\boldsymbol{f}_{\text {Doppler }}(\mathrm{Hz})$ から可動部の 速度 $\boldsymbol{v}\left(\mathrm{ms}^{-1}\right)$ が求められ, 求めた速度を時間積分, 時間微分
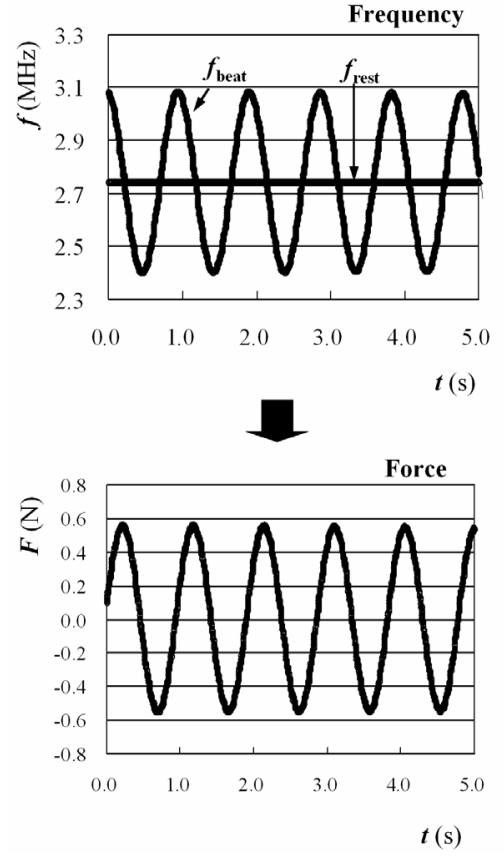

Fig. 4. Measurement result of free-swing.

することにより可動部の位置 $\boldsymbol{x}(\mathrm{m})$, 加速度 $\boldsymbol{a}\left(\mathrm{ms}^{-2}\right)$ がそれぞ れ求められる。振子の可動部に作用する力 $\boldsymbol{F}(\mathrm{N})$ は, 加速度 $\boldsymbol{a}\left(\mathrm{ms}^{-2}\right)$ と可動部質量 $\boldsymbol{M}(\mathrm{kg})$ から慣性の法則より次式で求め る。

$$
\boldsymbol{F}=\boldsymbol{M a}
$$

\section{4. 実験結果}

〈4·1〉 Free-swing Measurement 振子の復元力 $\boldsymbol{F}_{\text {restoring }}$ を評価するため, フリースイング試験を行った。実 験では，可動ベースを“position-2”にセットし可動部を前 後にスイングさせる。測定時閒はおよそ 9 秒である。Fig. 5 は, スイング運動における可動部の位置 $\boldsymbol{x}$ の振幅の減衰を 示している。スイング運動の $\mathrm{n}$ 番目のピークの振幅を $\mathrm{X}_{\mathrm{n}}$,

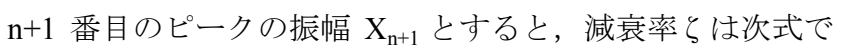
表される。

$$
\zeta=\log _{\mathrm{e}}\left(\mathrm{X}_{\mathrm{n}} / \mathrm{X}_{\mathrm{n}+1}\right) / 2 \pi
$$

振幅の最大值付近では, 值の変動がみられた。これは, 振 子が振幅の最大值付近でほぼ静止状態となる際に, 装置か らの振動が糸を通して振子に伝わるためであると考えられ る。この装置からの振動の影響を除去するため, 11 個の移 動平均化処理を行い, 最大值を求めた。シリコンゲル片の ような粘弾性材料の減衰率は， $0.05 〜 1.0$ 程度であることか らも，今回の実験における減衰は十分に小さいと言える。

Fig. 6 は, 位置 $\boldsymbol{x}$ に対する復元力 $\boldsymbol{F}_{\text {restoring }}$ の変化を示して いる。Fig. 6 より, 位置 $\boldsymbol{x}$ と復元力 $\boldsymbol{F}_{\text {restoring }}$ との間に明確な 線形関係が確認できる。グラフから, 復元力 $\boldsymbol{F}_{\text {restoring }}$ を表す 直線回帰式は次式のように求められた。

$$
\boldsymbol{F}_{\text {regression }}=-33.456 \boldsymbol{x}
$$

Fig. 6 には，(6)式で表される直線回帰式 $\boldsymbol{F}_{\text {regression }}$ も示して いる。求めた直線回帰式の決定係数 $\mathrm{R}^{2}$ は, およそ 0.9991 で 


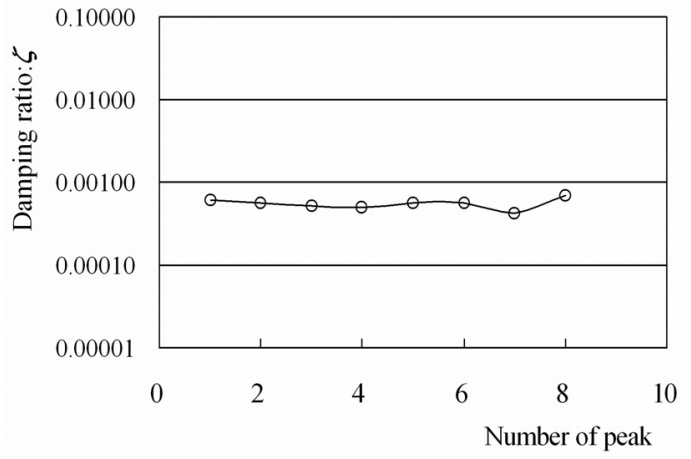

Fig. 5. Damping ratio of force.

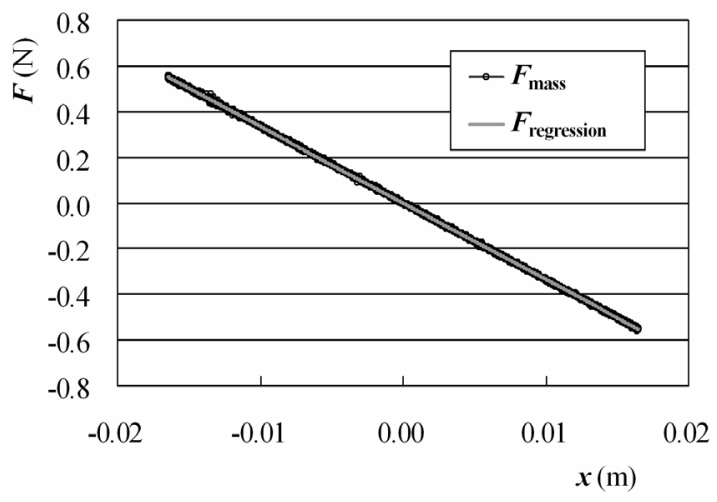

Fig. 6. Restoring force of the pendulum.

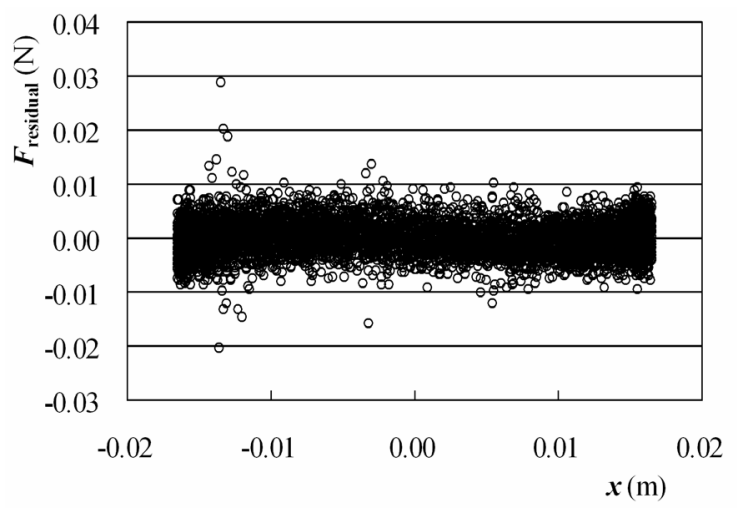

Fig. 7. Residual force against position.

ある。振子の復元力の補正は, 直線回帰式 $\boldsymbol{F}_{\text {regression }}$ を測定 結果から引くことにより行われる。振子の復元力を $\boldsymbol{F}_{\text {restoring, }}$, 残りの力を $\boldsymbol{F}_{\text {residual }}$ として次式で表す。

$$
\boldsymbol{F}_{\text {residual }}=\boldsymbol{F}_{\text {restoring }}-\boldsymbol{F}_{\text {regression }}
$$

Fig. 7 には，同一のフリースイング実験における， ( 7 )式で 表される残りの力を示している。残りの力 $\boldsymbol{F}_{\text {residual }}$ の RMS 值は, 約 $0.0032 \mathrm{~N}$ である。位置 $\boldsymbol{x}=-0.012 \mathrm{~m}$ 付近でやや大き な值を示しているが，全体的には位置への力の依存性が観 察されないことから, 回帰式の係数は適切であると言える。

〈4·2〉 Collision Measurement 衝突実験では, 可動 ベースを “position-1”にセットし，質量を試料と衝突させ る。質量に作用する全ての力は, フリースイング実験と同

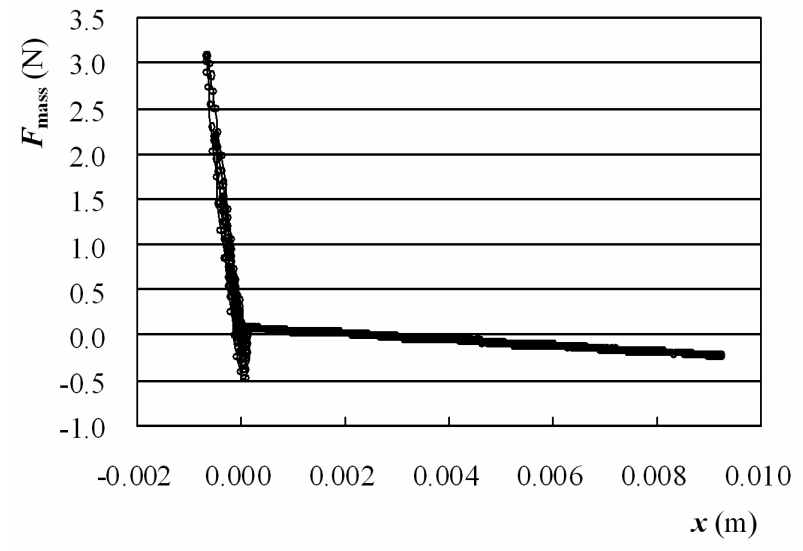

(a) $\boldsymbol{F}_{\text {mass }}$

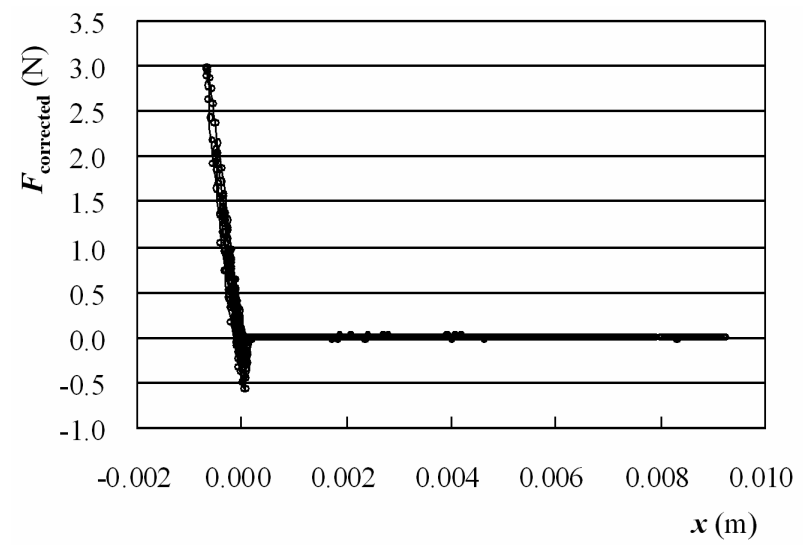

(b) $\boldsymbol{F}_{\text {corrected }}$

Fig. 8. Impact force against position.

様の方法から加速度と質量の積によって計算される。

Fig. 8 は, 11 回の連続した衝突について, 位置に対する力 の変化を示している。(a)は, 復元力を含んだ力 $\boldsymbol{F}_{\text {mass }}$, (b)は 復元力を補正した力 $\boldsymbol{F}_{\text {corrected }}$ を示している。 $\boldsymbol{F}_{\text {corrected }}$ は次式 で求められる。

$$
\boldsymbol{F}_{\text {corrected }}=\boldsymbol{F}_{\text {mass }}-\boldsymbol{F}_{\text {regression }}
$$

グラフでは, 可動部と試料との衝突開始位置を $\boldsymbol{x}=0$, 時刻 を $\boldsymbol{t}=0$ としている。(a)に示したグラフより, 可動部とシリ コンゲル片が衝突していない部分 $(\boldsymbol{x}>0)$ において $\boldsymbol{F}=0$ に ならない。これにより, 測定された力には復元力 $\boldsymbol{F}_{\text {restoring }}$ の 影響が現れていることがはっきりと確認できる。

補正には, フリースイング実験から求めた直線回帰式(6) を使用する。補正した力 $\boldsymbol{F}_{\text {corrected }}$ は, 衝突実験の間中, シリ コンゲル片から質量に作用する力 $\boldsymbol{F}_{\text {material }}$ として見積もられ る值である。質量からシリコンゲル片に作用する力は作用 反作用の原理に従い, $-\boldsymbol{F}_{\text {material }}$ と表せる。補正した力は, $\boldsymbol{x}$ $>0$ の部分において力がほぼゼロを示していることから, 適 切な補正が行われ，シリコンゲル片から質量に作用する力 として見積もることが出来たと言える。

Fig. 9 は, Fig. 8(b)における衝突部分の拡大図を示してい る。Fig. 9 より, シリコンゲル片の粘性によって生じる弾性 ヒステリシスがはっきりと観察される。1 回目の衝突におい 


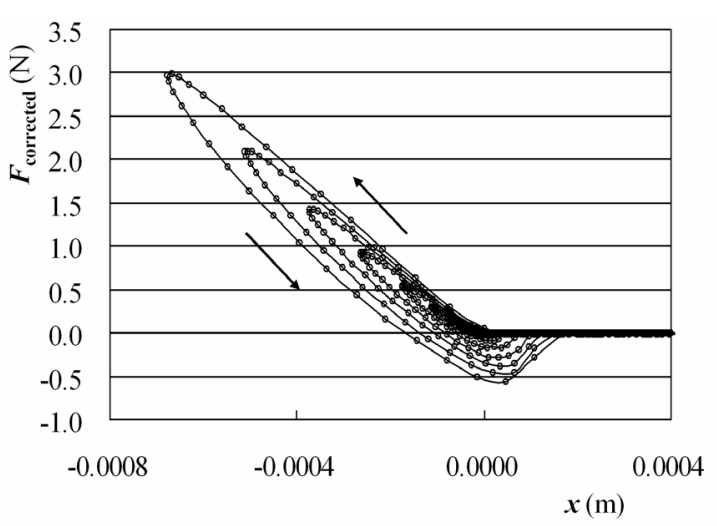

Fig. 9. Impact force against position.

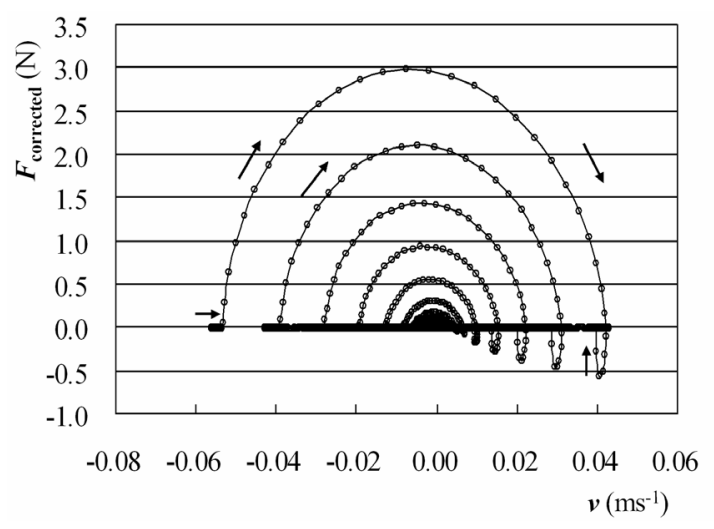

Fig. 10. Change force against velocity.

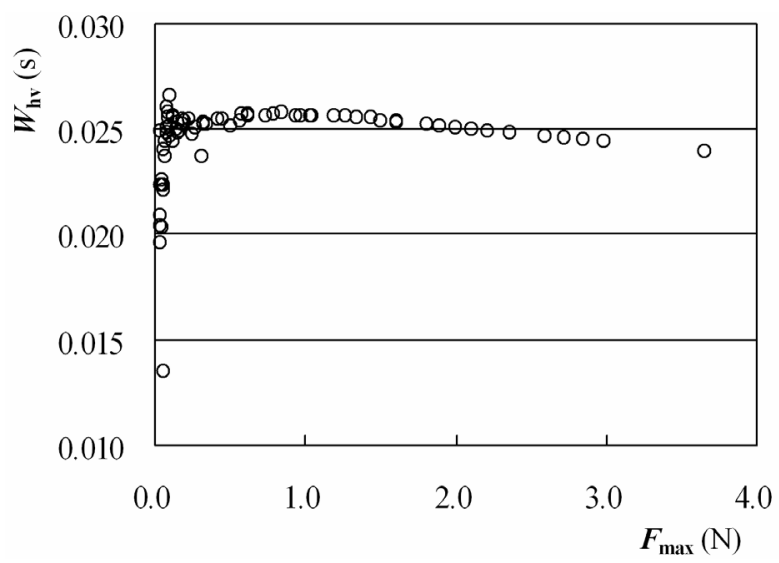

Fig. 11. The full width at half maximum of the impulse, $\boldsymbol{W}_{\mathbf{h v}}$, against the maximum value of the impact force, $\boldsymbol{F}_{\mathbf{m a x}}$.

て, 力が最大值約 $2.99 \mathrm{~N}$ に達した時の押し込み深さは約 -0.742 mm である。最大の押し込み深さ, 寸なわち $\boldsymbol{x}$ が負 の方向に最大となる位置は約一 $0.749 \mathrm{~mm}$ で，この時の力は 約 $2.97 \mathrm{~N}$ である。振子がシリコンゲル片から完全に離れた 位置は, 衝突開始位置よりも約 $95 \mu \mathrm{m}$ ずれた位置となり, 力は負の值を示している。これは, シリコンゲル片の固着 によるものと考えられる。曲線（F-x) で囲まれた面積は， シリコンゲル片が受け取ったエネルギーに相当する。この エネルギーは，シリコンゲル片と可動部の衝突時に試料内

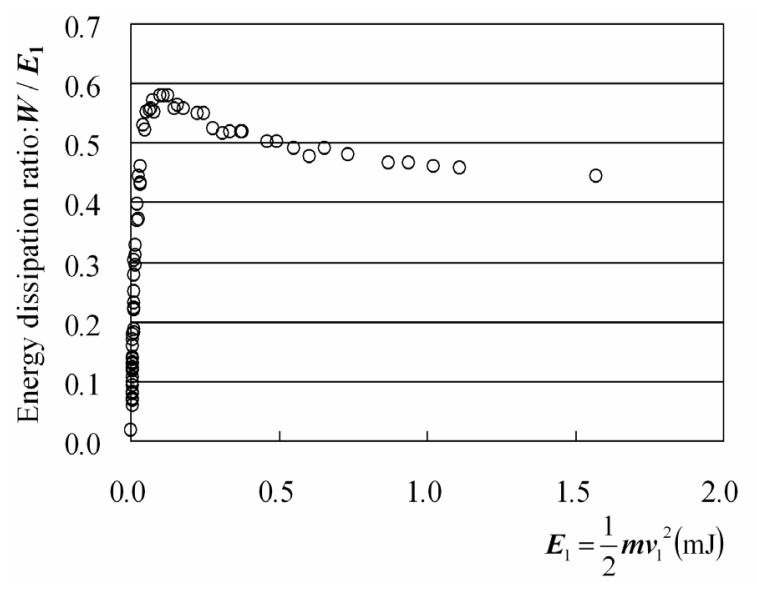

Fig. 12. Relationship between the energy dissipation ratio, $\boldsymbol{W} / \boldsymbol{E}_{1}$, and the initial kinetic energy of the moving part, $(1 / 2) \boldsymbol{m} \boldsymbol{v}_{1}^{2}$.

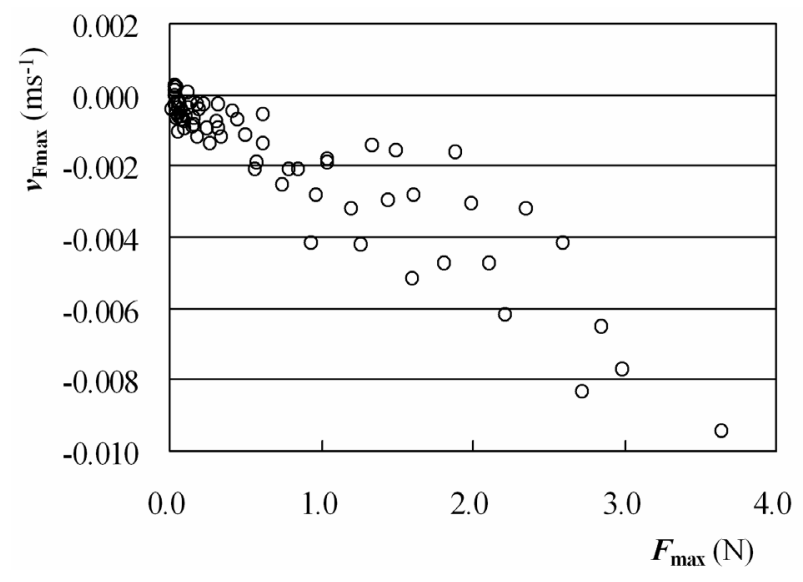

Fig. 13. Change in the velocity where the force has its maximum, $\boldsymbol{V}_{F \max }$, against the maximum value of the impact force, $\boldsymbol{F}_{\max }$.

部に熱エネルギーとして散逸したと考えられる。1 回目の衝 突において，振子がした仕事 $\boldsymbol{W}$ は，運動曲線に沿った力 $\boldsymbol{F}$ の積分として次式で表され, 約 $0.51 \mathrm{~mJ}$ と計算される。

$$
\boldsymbol{W}=\int(-\boldsymbol{F}) \mathrm{d} \boldsymbol{x}
$$

Fig. 10 は, 速度 $\boldsymbol{v}$ と補正した力 $\boldsymbol{F}_{\text {corrected }}$ の関係を示してい る。1 回目の衝突において, 力が約 $2.99 \mathrm{~N}$ の最大值に達し た時の速度 $\boldsymbol{v}_{\text {Fmax }}$ は, およそー0.0077 $\mathrm{ms}^{-1}$ である。衝突前後 の速度はそれぞれ， $\boldsymbol{v}_{\mathbf{1}}=-0.053 \mathrm{~ms}^{-1}, \boldsymbol{v}_{\mathbf{2}}=0.039 \mathrm{~ms}^{-1}$ 。運動 エネルギーの変化 $\boldsymbol{E}_{\mathbf{2}}-\boldsymbol{E}_{\mathbf{1}}$ は, 約 $0.49 \mathrm{~mJ}$ である。 $\boldsymbol{E}_{\mathbf{1}}, \boldsymbol{E}_{\mathbf{2}}$ は それぞれ衝突前の運動エネルギー, 衝突後の運動エネルギ 一であり，次式で表される。

$$
\begin{aligned}
& E_{1}=M v_{1}^{2} / 2 \\
& E_{2}=M v_{2}^{2} / 2
\end{aligned}
$$

(9)式によって得られた仕事量 $\boldsymbol{W}$ と運動エネルギーの変化 量 $\boldsymbol{E}_{\mathbf{2}}-\boldsymbol{E}_{\mathbf{1}}$ にわずかなずれが生じた。これは, 今回の実験に おける時間分解能では, 力の微小な変化を十分に捉えきれ なかったためと考える。そのため, $\boldsymbol{F}-\boldsymbol{x}$ のグラフから積分に よって求めた值と運動エネルギーの変化量の值が完全には 
一致しなかったのだと考えられる。

Fig. 11〜Fig. 13 には 74 回分の衝突データを示している。 Fig. 11 は, 衝撃の半值幅 $\boldsymbol{W}_{\mathbf{h v}}$ と衝撃力の最大值 $\boldsymbol{F}_{\mathbf{m a x}}$ の関係 を示している。力の最大值が小さくなるに伴い，半值幅は 増加している。これは, バネ定数が小さくなっていくこと を示している。しかし，力の最大值が $0.1 \mathrm{~N}$ より小さい条件 では, 逆に力の最大值が小さくなるにつれて半值幅が小さ くなる。すなわち，バネ定数が大きくなる。以降では，半 值幅が小さい。これは，シリコンゲル片が漸軟性から漸硬 性へと変化するバネ特性が原因と考えられる。

Fig. 12 は，エネルギー損失の割合 $\boldsymbol{W} / \boldsymbol{E}_{1}=\mathbf{W} /\left(1 / 2 \boldsymbol{m} \boldsymbol{v}_{1}{ }^{2}\right)$ と初 期運動エネルギー $\boldsymbol{E}_{1}=1 / 2 \boldsymbol{m} v_{1}^{2}$ の関係を示している。 $\boldsymbol{W} / \boldsymbol{E}_{1}$ は，試料の減衰比に関係する。シリコンゲル片の粘弾性挙 動は，歪み速度が高速になるとゲル状の領域からガラス状 の領域に変化する。ガラス領域からゲル領域へと変化する 際, 減衰比は急激に変化する。その変化がグラフに現れて いる。グラフより，シリコンゲル片の減衰比は速度依存性 があることがわかる。

Fig. 13 は, 衝撃力の最大值 $\boldsymbol{F}_{\text {max }}$ と, 力が最大值に達した ときの速度 $\boldsymbol{v}_{\mathrm{Fmax}}$ との関係を示している。力の最大值が大き くなるのに伴い， $\boldsymbol{v}_{\mathrm{Fmax}}$ の值が減少している。これは，もし， シリコンゲル片が弾性の特性のみを持つ場合, 力が最大值 に達した時，速度 $\boldsymbol{v}=0$ となるはずであることから，シリコ ンゲルが弾性の特性だけではなく粘性の特性も持ち合わせ ていることを表している。

\section{5. 不確かさ評価}

本実験における不確かさ要素は, 2 つの要素の合成と考え る。

$$
\mathrm{U}=\sqrt{\mathrm{U}_{\mathrm{A}}^{2}+\mathrm{U}_{\mathrm{B}}^{2}}
$$

$\left(\mathrm{U}_{\mathrm{A}}\right)$ ゼロ点に関する不確かさ

$\left(\mathrm{U}_{\mathrm{B}}\right)$ 可動部に作用する慣性力測定のスケールの不確かさ

〈5·1〉 ゼロ点に関する不確かさ Fig. 8(b)に示され たグラフで, $0.0 \mathrm{~mm}<\boldsymbol{x}<1.0 \mathrm{~mm}$ の範囲において, 衝突前 後の補正した力の平均值，標準偏差，RMS 值はそれぞれ -3.31 mN，3.45 mN，4.78 mN である。 $4.78 \mathrm{mN}$ の RMS 值 は, 質量の機械的振動による不確かさ, 振子の復元力補正 式の不確かさ，レーザの周波数安定性，光波干涉計を用い た周波数測定の不確かさを含むゼロ点の不確かさの合計に 相当する。従って, ゼロ点に関する標準不確かさは, $4.78 \mathrm{mN}$ と推定される。

〈5·2〉可動部に作用する慣性力測定のスケールの不確 かさ

$\langle 5 \cdot 2 \cdot 1\rangle$ 光軸のアライメント 光軸合せにおける最 大の誤差要因は, 約 $1 \mathrm{mrad}$ の不確かさを持つレーザビーム の傾き角設定である。これは, 約 $5 \times 10^{-7}$ の速度の相対不確 かさとなり，無視できる。

$\langle 5 \cdot 2 \cdot 2\rangle$ 周波数安定性実験で使用した周波数の安 定性の不確かさは，およそ $1 \times 10^{-6}$ で，これは無視できる。 $\langle 5 \cdot 2 \cdot 3\rangle$ 質 量 可動部質量の標準不確かさは $0.01 \mathrm{~g}$ で，これは $1.27 \times 10^{-5}$ の力測定における相対的な標準 不確かさに相当し，無視できる。

$\langle 5 \cdot 3\rangle$ 総合相対標準不確かさ 上記に述べた〈5・1 ， $\langle 5 \cdot 2\rangle$ 節の不確かさ要素から, 不確かさは $U_{\mathrm{A}}$ が支配的で, 本実験における総合標準不確かさは約 $4.78 \mathrm{mN}$ である。こ れは, 本実験で可動部に作用した力の最大值 $\left(\boldsymbol{F}_{\text {max }}=3.64 \mathrm{~N}\right)$ の約 $0.13 \%$ に相当する。

\section{6. 考 察}

本実験では，これまでの浮上質量法で用いてきた空気軸 受の代わりに振子を用いて可動部を支持し, 衝突実験を行 った。以前に提案していた振子は，4本のワイヤーで支持さ れていて, 振子に初速を与える際の糸を切ったことによる 振動や, 衝突した際の衝撃によって横方向へ振子がぶれて しまい, 可動部の動きを一方向に制御することが困難であ った。4 本のワイヤーで支持する振子機構を用いた場合のゼ 口点に関する不確かさは，0.4\%であった ${ }^{(13)}$ 。一方，今回使 用した 6 本のワイヤーで作る三角形の形状により, 可動部 の移動方向を一方向に制限したため, 従来の欠点が解消さ れ，機械的な安定性が改善したものと考える。また，ギタ 一の弦調整に使用するペグを用いてワイヤーの長さ調節を した。これにより長さ調節が容易になり，実験装置のセッ トアップの簡便化につながっていると考える。

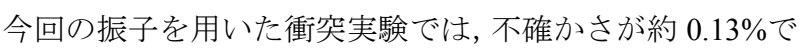
ある。各実験で使用した材料は異なるが，振子機構を用い た場合にも, 空気軸受を用いた場合 ${ }^{(7) \sim(10)}$ と同程度の精度で 材料の力学特性を測定できることが確認された。振子機構 の糸の鉛直方向とな寸角度が小さく単振動とみなせる場合 では, 安価で小型の材料試験機としての実用化に向けた期 待が高まる。

\section{7. まとめ}

今回，以前提案した 4 本ワイヤー支持の振子を改良した， 6 本のワイヤー支持の振子機構を用いてシリコンゲル片の 材料試験を行った。6本のワイヤーを用いることにより，振 子の可動方向の制限ができ, 高精度にシリコンゲル片の材 料試験を行うことが出来た。今後, 干渉計の光源に LD を使 用するなど更なる低コスト化を図ることで，材料試験への 応用が期待できる。また, 今後, 振子機構を用いた場合の, 温度による影響について調べる。

\section{謝 辞}

本研究は, 科学研究補助金(B) 19360185 (KAKENHI 1960185)の助成によるものである。

(平成 20 年 6 月 6 日受付, 平成 20 年 8 月 1 日再受付)

\section{文献}

(1) R. Kumme : "Investigation of the comparison method for the Dynamic calibration of force transducers", Measurement, Vol.23, pp.239-245 (1988) 
(2) Y.-K. Park, R. Kumme, and D.-I. kang : "Dynamic investigation of a binocular six-component force-moment sensor", Sci. Technol, Vol.13, pp.1311-1318 (2002)

( 3 ) Y-.K. Park, R. Kumme, and D-.I. kang : "Dynamic investigation of a three-component force-moment sensor", Meas. Sci. Technol, Vol.13, pp.654-659 (2002)

(4) Y. Fujii : "Measurement of impulse response of force transducers", Rev. Sci. Instrum., Vol.72, No.7, pp.3108-3111 (2001)

( 5 ) Y. Fujii : "Proposal for a step response evaluation method for force transducers", Meas. Sci. Technol., Vol.14, pp.1741-1746 (2003)

(6) Y. Fujii : "A method for calibrating force transducers against oscillation force”, Meas. Sci. Technol., Vol.14, pp.1259-1264 (2003)

( 7 ) Y. Fujii, D. Isobe, S. Saito, H. Fujimoto, and Y. Miki : "A method for determining the impact force in crash testing", Mechanical Systems and Signal Processing, Vol.14, No.6, pp.959-965 (2000)

(8) Y. Fujii and T. Yamaguchi : "Method for evaluating material viscoelasticity”, Rev. Sci. Instrum, Vol.75, No.1, pp.119-123 (2004)

(9) T. Suzuki, Y. Fujii, and J. Valera : "Optical method for strength test for general industrial products", Mechanical Systems and Signal Processing, Vol.20, No.3, pp.735-744 (2006)

(10) H. Ito and Y. Fujii : "Evaluation of mechanical response of human palm to small impact force”, T IEE Japan, Vol.126-A, No.6, pp.297-302 (2007-6) (in Japanese)

伊藤 瞳・藤井雄作 :「手のひらの力学特性評価」, 電学論 A, 126, 6 , pp.297-302 (2007-6)

(11) Y. Fujii : "Measurement of force acting on a moving part of a pneumatic linear bearing", Rev. Sci. Instrum., Vol.74, No.6, pp. 3137-3141 (2003)

(12) Y. Fujii and T. Yamaguchi : "Method for evaluating material viscoelasticity", Rev. Sci. Instrum, Vol.75, No.1, pp.119-123 (2004)

(13) Y. Fujii : "Pendulum for precision force measurement", Rev. Sci. Instrum, Vol.77, No.3, pp.035111-1-5 (2006)

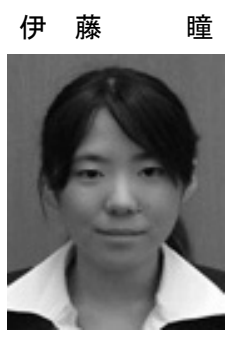

（非会員） 1983 年 10 月 18 日生。2006 年 3 月 群馬大学 工学部 電気電子工学科卒業。同年 4 月群馬大学 大学院 工学研究科 電気電子工学 専攻入学。現在，浮上質量法を用いた生体の力 学特性の高精度評価法に関する研究に従事。

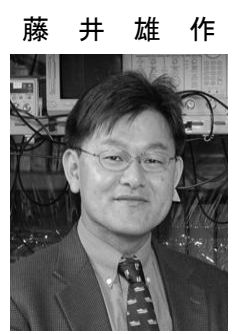

(正員） 1965 年 9 月 15 日生。1989年 3 月東京 大学 工学部船舶工学科卒業。1992 年 3 月東京 大学 大学院 工学系研究科修士課程 (船舶海洋 工学専攻）修了。同年 4 月川崎製鉄（株）入社。 1996 年 4 月工業技術院計量研究所入所。2 2004 年 4 月群馬大学教授。現在, 計測工学の研究に 従事。IEEE 会員。

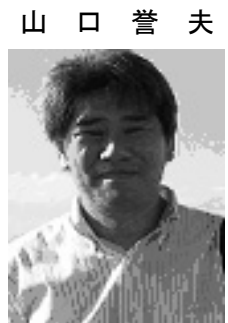

（非会員） 1963 年 3 月 14 日生。1986 年 3 月名 古屋大学 工学部卒業。同年, 富士重工業（株） スバル研究所・音振動グループ, CAE グループ に所属。2000 年群馬大学 機会システム工学科 准教授。現在, 自動車や構造物の振動・防音特 性, 柔軟構造の非線形, カオス振動の研究に従 事。

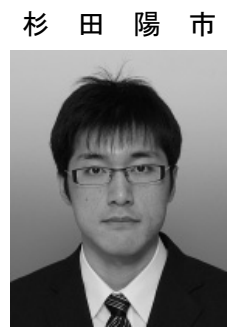

(非会員) 1983 年 5 月 4 日生。 2007 年 3 月群 馬大学 工学部 電気電子工学科卒業。同年 4 月 群馬大学 大学院 工学研究科 電気電子工学専 攻入学。現在, 無重力環境における質量測定器 に関する研究に従事。

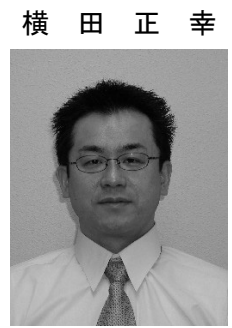

（非会員） 1967 年 1 月 31 日生。1998 年群馬大 学大学院工学研究科博士後期課程修了。2000 年から同大学電気電子工学科に助手として勤 務。主として, 光ファイバセンサ応用, 干渉計 計測などの光応用計測に従事。現在，同科の助 教。工学博士。 